\title{
Delayed expression of apoptosis in human lymphoma cells undergoing low-dose taxol-induced mitotic stress
}

\author{
R Allman*, ', RJ Errington ${ }^{2}$ and PJ Smith ${ }^{2}$ \\ 'Cancer Research Wales Laboratories, Velindre NHS Trust, Whitchurch, Cardiff CFI 4 2TL, Wales, UK; ${ }^{2}$ Department of Pathology, University of Wales \\ College of Medicine, Heath Park, Cardiff CFI4 4XN, Wales, UK
}

\begin{abstract}
The links between low-dose range taxol-induced mitotic arrest and the subsequent engagement of apoptosis are important for identifying the routes to therapeutic action. Here we have investigated the timing of cell-cycle perturbation and cell death responses following continuous exposure to clinically relevant drug concentrations ( $1-20 \mathrm{~nm}$ ). Following $8 \mathrm{~h}$ of exposure to taxol, the cell line $\mathrm{DoHH} 2$ (p53 wild type) exhibited mitotic arrest and engagement of apoptosis, whereas the cell line SU-DHL-4 (p53 mutant) breached cell-cycle arrest with progression to an abnormal cycle and a $24 \mathrm{~h}$ delay in the engagement of apoptosis. Imaging showed equivalent dysfunction of mitotic spindles in both cell lines. The results of kinetic analyses indicated that although cell death may occur at different stages of progression through mitosis and subsequent cell cycles, the overall kinetics of cell death relate to the rate of arrival at a critical event window in the cell cycle. We propose a simple model of low-dose taxol-induced cell death for cycling populations in which mitotic stress acts as a primary trigger for apoptosis with equivalent but potentially delayed outcomes. This view provides a rationale for the clinical effectiveness of this agent, independent of the initial capacity of the tumour cell to engage apoptosis due, for example, to mutant p53 expression. The results provide a perspective for the design of combination regimens that include low-dose taxol and a component that may disturb mitotic delivery.
\end{abstract}

British Journal of Cancer (2003) 88, 1649-1658. doi:I0.1038/sj.bjc.6600905 www.bjcancer.com

(C) 2003 Cancer Research UK

Keywords: paclitaxel; cell cycle; mitosis; apoptosis; p53

Paclitaxel (taxol) is a complex diterpenoid isolated from the inner bark of the Western yew tree - Taxus brevifolia (Wani et al, 1971). This naturally occurring agent has been shown to have significant activity against advanced ovarian cancers (McGuire et al, 1989; Runowicz et al, 1995), metastatic breast cancers (Holmes et al, 1991; Hortobagyi and Holmes, 1996), and leukaemias (Rowinsky et al, 1989) refractory to standard chemotherapy. It has also shown some activity against various other tumour types (Etlinger, 1993; Forastiere, 1993; Einzig and Wiernik, 1995; Edelman and Gandara, 1996). Although the mechanism by which stable microtubules are induced by taxol are well established (Schiff et al, 1979; Rao et al, 1992, 1994), the molecular links between tubulin polymerisation, cell-cycle arrest, and ultimately cell death are not so well characterised. Given the broad spectrum of activity of taxol with regard to tumour type and genetic background, it is important that these mechanisms are resolved. In particular, whether a mitotic arrest is essential for taxol-induced cell death and if so does a functional spindle checkpoint affect survival outcome. Many successful cancer treatments rely upon combinations of therapeutic agents, and it is important for the development of such regimens so that the mechanism and the complex kinetics of cellular response to taxol are clarified. In particular, combination with agents that have different cell-cycle specificities may produce effects that abrogate taxol action.

\footnotetext{
*Correspondence: Dr R Allman;

E-mail: Richard.Allman@velindre-tr.wales.nhs.uk

Received 26 June 2002; revised 4 February 2003; accepted 21 February 2003
}

Taxol appears to target microtubules specifically both in vitro and in vivo (Schiff and Horwitz, 1980, 1981; Manfredi et al, 1982; Manfredi and Horwitz, 1984; De Brabender et al, 1996). However, unlike classical antimicrotubule agents, such as colchicine and vinblastine, that induce microtubule disassembly and paracrystal formation (Wilson et al, 1974), the antitumour activity of taxol has been demonstrated to be associated with microtubule stabilisation (Manfredi and Horwitz, 1984; Horwitz et al, 1986) and with the arrest of cells in the G2/M phase of the cell cycle (Rowinsky et al, 1990; Slichenmyer and von Hoff, 1991; Rowinsky et al, 1992). In addition to stabilising microtubules and inducing cell-cycle arrest, taxol has also been demonstrated to induce apoptosis in a variety of solid tumour cells (Cheng et al, 1995; Jordan et al, 1996; Milross et al, 1996). However, the dependence of taxol-induced cell death on cell-cycle-specific arrest is not clear. Apoptosis is an important factor in describing population responses to DNA damage and is related in part to p53 function. For example, while wild-type p53 cells undergo apoptosis after exposure to radiation, p53 mutant cells show delays in the progression to apoptosis (Lowe et al, 1993b). Dysfunction of p53-dependent pathways can allow tumour cells to evade the checkpoint controls and apoptosis, thereby gaining a selective advantage in attempting to overcome therapy (Lowe et al, 1993a). As a consequence, cancers with TP53 mutations tend to have a worse prognosis for responses to chemotherapy than those showing wild-type alleles (Callahan, 1992).

The situation regarding the role of TP53 dysfunction in the response of tumour cells to taxol is more complicated with several contradictory reports appearing in the literature. One report describes that in different cultured fibroblast cell lines, disruption 
of wild-type p53 function resulted in increased sensitivity of cells to taxol treatment compared to cells expressing wild-type p53 (Wahl et al, 1996). Conversely in an ovarian cancer cell line expressing wild-type p53, the disruption of p53 by transfection with the E6 protein of human papilloma virus type 16 led to a decrease in sensitivity to taxol (Wu and El-Deiry, 1996). It has also been reported that the introduction of wild-type p53 into an ovarian cancer cell line not expressing p53 resulted in no change to the tumour cell sensitivity to taxol (Graniela Sire et al, 1995). The situation is further complicated with taxol being reported to increase the levels of p53 protein in some cell types (Tishler et al, 1995) but not in others (Graniela Sire et al, 1995).

Regardless of p53 status, the sequence of signals triggering the apoptotic response may also be dependent upon taxol concentration. Thus, when cells are exposed to low concentrations of taxol $(1-100 \mathrm{nM})$, which do not affect the overall cytoskeletal microtubule structures (Jordan et al, 1993), it has been proposed that triggering of the mitotic spindle checkpoint promotes arrest and apoptosis directly (Sorger et al, 1997). The mitotic spindle checkpoint is a signal transduction pathway that links a kinetochore-associated sensor, which monitors the appropriate connection between mitotic spindles and chromosomes, to an output that arrests the cell cycle (Sorger et al, 1997). Several mammalian gene products have been identified to function at the spindle assembly checkpoint including the Mad (mitotic arrest defective) proteins Mad 1-3, the Bub (budding uninhibited by benomyl) proteins, Bub 1-3 and Mps1. Treatment with taxol or nocodozole upregulates Bub3 (Martinez-Exposito et al, 1999) and expression of dominant-negative Bub1 inhibits nocadazoleinduced apoptosis (Taylor and McKeon, 1997), suggesting that protracted activation of these gene products may play a role in apoptosis induction following a mitotic arrest. It has also been proposed that abnormal mitotic exit provides the signal for apoptosis (Jordan et al, 1996). Wang et al (2000), suggesting that these two events are the two possible triggers for cell death following mitotic arrest or delay. Our hypothesis was that arrival of cells at this critical cell-cycle phase is the 'event' that triggers processes that end in cell death, although timing of the overt expression of cell death will depend upon genetic status. Thus, the rate of delivery to that event window determines future expression of cell death, and the cell-cycle position at which cell death actually occurs may be misleading in terms of event linkage.

This study was designed to identify the links between mitotic arrest, and subsequent engagement of apoptosis, by investigating the timing of these responses following exposure to clinically relevant concentrations of taxol and over a sufficiently long period to identify fully response outcomes. This is important since different routes of taxol evasion prior to commitment to cell death could provide routes for drug resistance phenotype development. We have used two cell lines that represent different extremes of the apoptotic responses to taxol in a multiparameter flow cytometric study, which delineated cell-cycle traverse and correlated landmark cell-cycle events with the subsequent engagement and kinetics of apoptosis. Cell-cycle landmarks were confirmed using dual parameter measurements of DNA and either cyclin B1 (Gong et al, 1995; Widrow et al, 1997) or the mitosis-specific protein MPM2 (Juan et al, 2001).

\section{MATERIALS AND METHODS}

\section{Cell lines and culture conditions}

Two human follicular B-lymphoma cell lines were used in this study. DoHH2 was a kind gift from Dr JC Kluin-Nelemans [Leiden, The Netherlands; (Kluin-Nelemans et al, 1991)], and SU-DHL-4 was provided by Professor FE Cotter (Epstein et al, 1978). DoHH2 was routinely maintained in RPMI 1640 supplemented with 5\%
FCS. SU-DHL-4 was cultured in RPMI 1640 supplemented with $10 \%$ FCS. All growth media were supplemented with $100 \mathrm{U} \mathrm{ml}^{-1}$ penicillin, $100 \mu \mathrm{g} \mathrm{ml}^{-1}$ streptomycin, and $2 \mathrm{~mm}$ glutamine. The cells were passaged twice weekly at an initiating density of $5 \times 10^{4}$ cells ml ${ }^{-1}$ cultured at $37^{\circ} \mathrm{C}$ in a humidified atmosphere of $5 \% \mathrm{CO}_{2} / 95 \%$ air. The p53 status of DoHH2 (wild-type radiation response) and SU-DHL-4 (stabilised mutant) was confirmed by immunoblotting.

\section{Irradiation}

All irradiations were performed at room temperature in oxic conditions using a ${ }^{137} \mathrm{Cs}$ gamma source of $0.66 \mathrm{MeV}$ energy. The dose rate was $1.2 \mathrm{~Gy} \mathrm{~min}^{-1}$. Irradiations were usually completed within $10 \mathrm{~min}$.

\section{Flow cytometry}

Flow cytometric analyses were performed using a standard configuration FACScan equipped with an argon-ion laser (Becton Dickinson, Oxford, UK). Data from either 6000 or 10000 cells were recorded using CellQuest software (Becton Dickinson, Oxford, UK). Data analysis was performed using WinMDI (J Trotter, Scripps Research Institute, San Diego, USA). Cell debris was excluded from all the measurements on the basis of forward and orthogonal light scatter. In the case of DNA analysis, cell aggregates were excluded on the basis of pulse-width $v s$ pulsearea measurements of propidium iodide fluorescence. Normal human lymphocytes were used to monitor instrument performance and calibrate measurements of cellular DNA content.

\section{Single parameter DNA measurements}

Cell cultures were resuspended in phosphate-buffered saline (PBS). A volume of $125 \mu \mathrm{l}$ of propidium iodide $\left(0.4 \mathrm{mg} \mathrm{ml}^{-1}\right) /$ Triton X$100\left(1 \% \mathrm{v} \mathrm{v}^{-1}\right)$ was added to $1 \mathrm{ml}$ of cell suspension together with $50 \mu \mathrm{l}$ Ribonuclease A $\left(10 \mathrm{mg} \mathrm{ml}^{-1}\right)$ (Sigma, Poole, UK). Cells were incubated at $37^{\circ} \mathrm{C}$ for $10 \mathrm{~min}$ prior to FACS analysis. Normal human lymphocytes were used to monitor instrument performance and to calibrate measurements of DNA ploidy. Where required, DNA histograms were deconvoluted according to the protocol of Watson et al (1987) and Ormerod et al (1987).

\section{Annexin-V - FITC measurements}

In total, $0.5 \mathrm{ml}$ cells $\left(5 \times 10^{5}\right.$ cells $)$ were labelled using an AnnexinV-FITC labelling kit (Calbiochem-Novabiochem, Nottingham, UK). Briefly, cells were labelled directly in the culture medium using $1.25 \mu \mathrm{l}$ Annexin-V-FITC and $10 \mu \mathrm{l}$ of the supplied media binding reagent for $15 \mathrm{~min}$ at room temperature in the dark. Cells were centrifuged at $250 \mathrm{~g}$ for $5 \mathrm{~min}$ and resuspended in $0.5 \mathrm{ml}$ of binding buffer (10 mM HEPES pH 7.4, $150 \mathrm{~mm} \mathrm{NaCl}, 2.5 \mathrm{~mm} \mathrm{CaCl}_{2}$, $1 \mathrm{~mm} \mathrm{MgCl}_{2}, 4 \% \mathrm{BSA}$ ). A volume of $10 \mu \mathrm{l}$ propidium iodide $\left(30 \mu \mathrm{g} \mathrm{ml}^{-1}\right)$ was added and the samples analysed immediately by flow cytometry.

\section{Dual parameter cyclin B1/DNA and mitotic proteins/DNA measurements}

Approximately $5 \times 10^{5}$ cells were collected for each sample. Cells were washed with cold PBS, fixed in ice-cold 70\% ethanol, and then stored overnight at $4{ }^{\circ} \mathrm{C}$. Cells were washed in PBS and resuspended in $100 \mu \mathrm{l}$ PBS containing $1 \%$ bovine serum albumin (BSA). A volume of $10 \mu \mathrm{l}$ anti-cyclin B1 mouse monoclonal antibody (Dako, Ely, UK) or $10 \mu \mathrm{l}$ anti-mitotic proteins (clone MPM2) mouse monoclonal antibody (Dako, Ely, UK) was added and the cells stored overnight at $4^{\circ} \mathrm{C}$. Cells were washed twice in PBS and resuspended in $100 \mu \mathrm{l}$ PBS containing 1\% BSA. A volume of $10 \mu \mathrm{l}$ 
anti-mouse IgG - FITC monoclonal antibody (Dako, Ely, UK) was added and the cells incubated for $1 \mathrm{~h}$ at room temperature in the dark. Cells were washed twice in PBS to remove excess antibody and resuspended in $1 \mathrm{ml}$ propidium iodide $\left(10 \mu \mathrm{g} \mathrm{ml}^{-1}\right)$. A volume of $50 \mu \mathrm{l}$ of RNAse $\left(10 \mathrm{mg} \mathrm{ml}^{-1}\right)$ was added and the cells incubated for $30 \mathrm{~min}$ at room temperature prior to FACS analysis.

\section{Microtubules immunocytochemistry}

Approximately $10^{6}$ cells were collected for each sample. Cells were washed with cold PBS, fixed in $4 \%$ paraformaldehyde, and then stored overnight at $4{ }^{\circ} \mathrm{C}$. Cells were washed in PBS and rehydrated in PBS for $10 \mathrm{~min}$ at room temperature. Cells were permeabilised in $0.1 \%$ Triton $\mathrm{X}-100 / \mathrm{PBS}$ for $30 \mathrm{~min}$ at room temperature. Nonspecific antibody labelling was blocked using goat serum ( $1: 10$ dilution) for $1 \mathrm{~h}$ at room temperature. Anti- $\beta$-tubulin monoclonal antibody (clone TUB 2.1) (Sigma, UK) was added ( $1: 200$ dilution) for $1 \mathrm{~h}$ at $37^{\circ} \mathrm{C}$. Cells were washed four times to remove excess antibody. Goat-anti-mouse IgG-Cy3 monoclonal antibody (Amersham Pharmacia, Cardiff, UK) was added (1:100 dilution) for $30 \mathrm{~min}$ at $37^{\circ} \mathrm{C}$. Cells were washed three times in PBS to remove excess antibody. DNA was labelled using the red fluorescent probe DRAQ5 (Biostatus Ltd, Shepshed, UK) (Smith et al, 2000a). Cells were loaded with $10 \mu \mathrm{M}$ DRAQ5 for $10 \mathrm{~min}$ at room temperature and mounted without further washing.

\section{Confocal laser scanning microscopy}

A single optical slice dual channel image was acquired using a confocal laser scanning microscope (CLSM) (BioRad Microsciences Ltd, Hemel Hempsted, UK), equipped with a krypton/ argon ion laser and attached to a Zeiss Axiovert 135. DRAQ5 (DNA) was visualised using $647 \mathrm{~nm}$ excitation and detected at 680/ $30 \mathrm{~nm}$. Cy3 (tubulin) was excited at $568 \mathrm{~nm}$ and detected at 590/ $40 \mathrm{~nm}$.

\section{RESULTS}

\section{DNA damage response and cell-cycle checkpoint status}

The two cell lines SU-DHL-4 and DoHH2 both grow in suspension culture with doubling times of approximately 17 and $21 \mathrm{~h}$, respectively. To establish whether the two cell lines exhibit the expected differential pattern of cell-cycle arrest in response to ionising radiation (based upon their known p53 status), cultures were exposed to $4 \mathrm{~Gy}$ of $\gamma$-irradiation (preliminary observations indicated that this dose was suitable for inducing cell-cycle arrest without inducing a substantial cell kill). Figure 1 shows the typical changes in cell-cycle distribution of irradiated $\mathrm{DoHH}_{2}$ and SU-DHL-4 cells with a postirradiation incubation period of $14 \mathrm{~h}$. The DoHH2 cell line exhibits a retention of cells in G1 and an accumulation in $\mathrm{G} 2$ with a simultaneous reduction in the number of cells in $S$ phase, typical of a wild-type p53 response (Kuerbitz et al, 1992). In contrast, the SU-DHL-4 cells lack a G1/S arrest phenotype in response to ionising radiation and exhibit a greater accumulation of cells in G2/M with a concomitant reduction of the number of cells in both G1 and S phase, typical of a mutated p53 response (Kuerbitz et al, 1992). SU-DHL-4 cells were also more resistant to radiation-induced apoptosis than the DoHH2 cell line (data not shown). Immunoblotting confirmed the rapid radiation-induced changes in stabilisation of p53 in DoHH2 but not in SU-DHL-4.

\section{Taxol induces a G2/M arrest in both DoHH2 and SU-DHL-4}

To establish the general characteristics of the cell-cycle response to taxol, cells were exposed to taxol at varying concentrations in the clinically relevant low-dose range 1-20 nM (Huizing et al, 1993).
The preparation method for cell-cycle analysis does not require cell washing and, therefore, provides a high degree of retention of both apoptotic and mitotic nuclei (Smith et al, 2000b). Figure 2 shows typical DNA histograms obtained from both cell lines following treatment with $10 \mathrm{~nm}$ taxol. At $9 \mathrm{~h}$ following addition of taxol both cell lines exhibit an accumulation of cells in G2/M, this accumulation being more pronounced in the DoHH2 cell line, with $43 \%$ of the cells being in G2/M as opposed to $30 \%$ of the SU-DHL-4 line. Following $24 \mathrm{~h}$ of exposure to taxol, the majority of the DoHH2 cells (58\%) remain in a cell-cycle arrest. In the SU-DHL-4 line however, only $10 \%$ of cells were retained in $\mathrm{G} 2 / \mathrm{M}$ with the majority of cells appearing to have progressed to a polyploid generation demonstrating aberrant DNA contents. Thus, it appears that both cell lines are responding to taxol by showing compromised traverse of G2/M with cell-cycle arrest evident in DoHH2, whereas the duration of any arrest appears to be greatly reduced in the SU-DHL-4 (TP53-mutant) cell line.

Deconvolution of DNA content distributions obtained from cultures exposed to varying concentrations of taxol over a $24 \mathrm{~h}$ time period permitted the plotting of the kinetics of cell-cycle perturbation induced by taxol (Figure 3). Both DoHH2 and SUDHL-4 respond to taxol by a dose-dependent arrest in G2/M, with a concomitant reduction of the fraction of cells in both the G1 and $S$ phase. The results indicate that taxol elicits a cell-cycle arrest in DoHH2 cells at concentrations of 5, 10, and $20 \mathrm{~nm}$, and that this arrest is substantially maintained during the period of exposure to the drug. Although the same concentrations of taxol induce a cellcycle arrest in SU-DHL-4, the magnitude of this arrest is reduced compared to that for the DoHH2 line. Linear regression analysis of the data indicated that DoHH2 and SU-DHL-4 both exhibited a near maximal rate of accumulation in G2/M following exposure to $20 \mathrm{~nm}$ taxol, with rates of accumulation being 2.8 and $2.2 \%$ per $\mathrm{h}$, respectively. These rates of accumulation were maintained for approximately $20 \mathrm{~h}$, that is, approximately one full cell-cycle
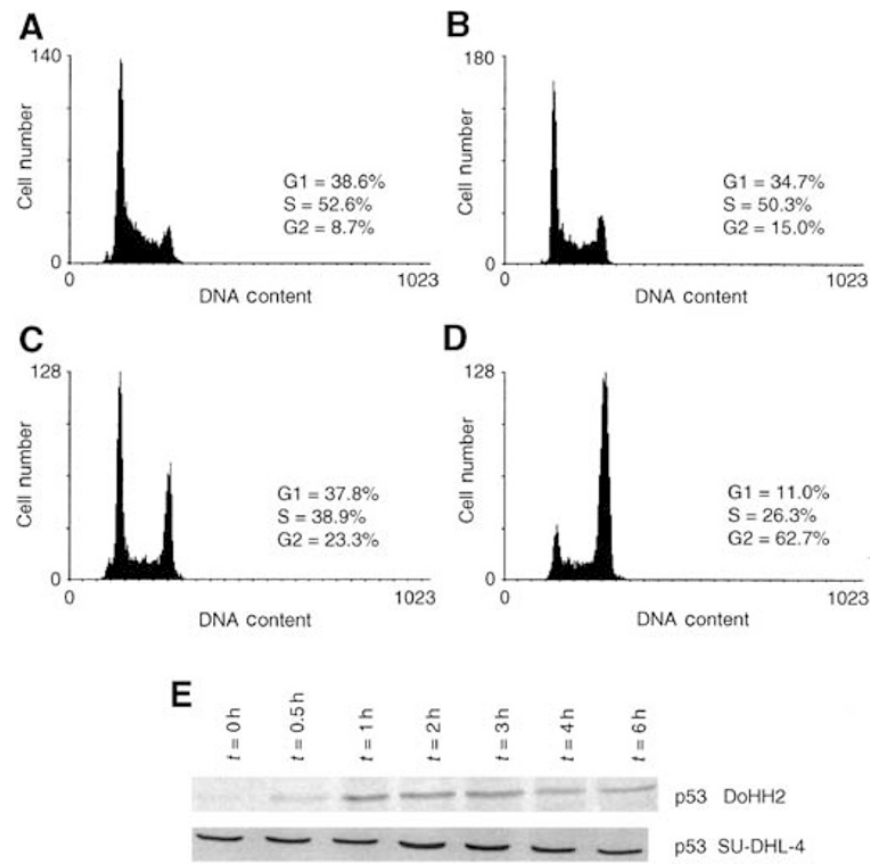

Figure I Differential cell-cycle arrest in response to ionising radiation. DNA distributions are (A) DoHH2 and (B) SU-DHL-4 under normal exponential growth conditions, and obtained $14 \mathrm{~h}$ following exposure to 4 Gy of ionising radiation (C) DoHH2, (D) SU-DHL-4. Data are representative distributions obtained from 6000 cells. (E) SDS-PAGE followed by immunoblotting for p53, analysis of cellular lysates from the two cell lines prepared at the indicated time points after irradiation at $6 \mathrm{~Gy}$. 

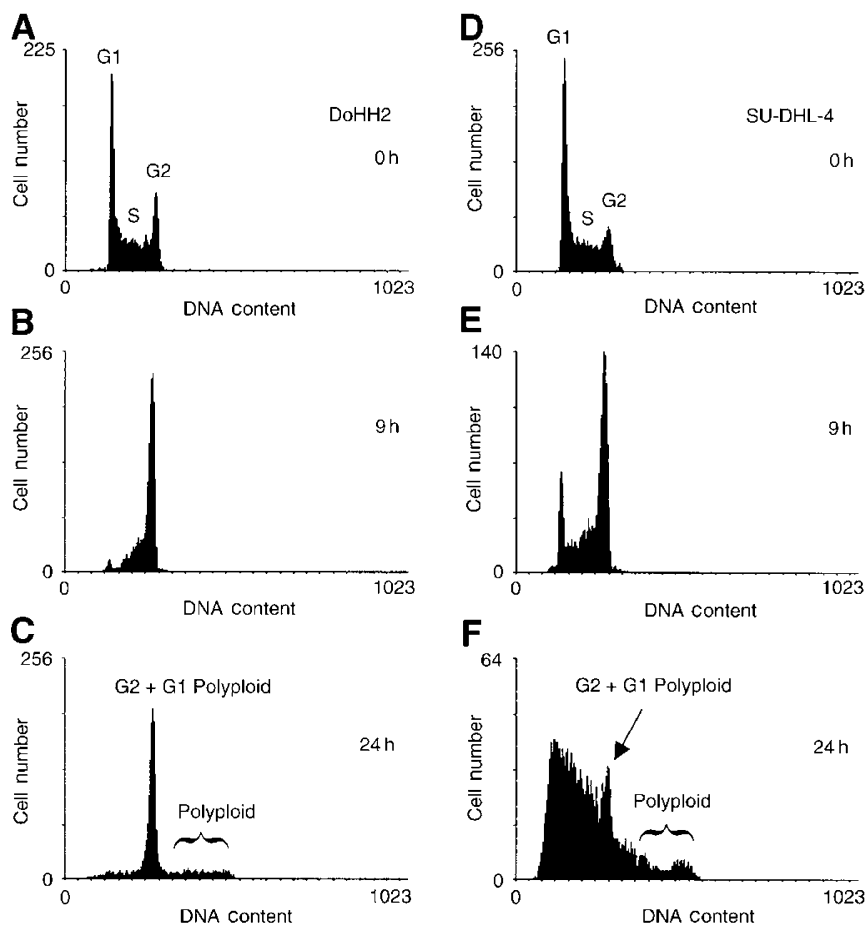

Figure 2 Differential G2/M arrest and progression to polyploidy in $\mathrm{DoHH} 2$ and $\mathrm{SU}-\mathrm{DHL}-4$ following continuous exposure to taxol. Cells were incubated with $10 \mathrm{~nm}$ taxol for the indicated times.

traverse period. However, an analysis of the DNA distributions (see Figure 2) indicates that at later time points $(>10 \mathrm{~h}$ ), both cell lines show evidence of progression to polyploidy, therefore the data plotted as G2/M will also contain G1 polyploid cells.

Thus, following taxol-induced cell-cycle arrest there are three possible outcomes for the cell depending on the dose of drug to which they are exposed. At low doses, cells may escape cell-cycle arrest and continue cycling normally. At higher doses, cells may experience a sustained cell-cycle arrest, or alternatively cells may breach the cell-cycle arrest and proceed to polyploidy. These three possible cell-cycle arrest events provide the key decision points that determine whether a cell subsequently survives the cytotoxic insult by taxol or proceeds to a programmed cell death (see Figure 10).

Taxol induces a sustained cell-cycle arrest in DoHH2 cells and a transient arrest in SU-DHL-4 cells

The differential pattern of cell-cycle arrest between the two cell lines was confirmed by dual parameter measurements of the mitosis-specific protein MPM2 vs DNA content (Figure 4). It can be seen that following an $8 \mathrm{~h}$ exposure to $10 \mathrm{nM}$ taxol, both cell lines show evidence of a subpopulation of MPM2-positive cells. However, this subpopulation is reduced in the SU-DHL-4 line as compared to the DoHH2 line. It is clear that following $24 \mathrm{~h}$ exposure to $10 \mathrm{~nm}$ taxol, the majority of the DoHH2 cells remain arrested in mitosis, while the majority of the SU-DHL- 4 cells have shown cycle progression and exhibit aberrant and polyploid DNA contents, which was also demonstrated in the single parameter DNA measurements (see Figure 2).

To confirm the observed differences in the duration of mitotic arrest, we also measured cyclin B1 protein expression following exposure to taxol. Cyclin B1 is primarily synthesised during G2 and is rapidly degraded at the end of mitosis (Pines and Hunter, 1989). Dual parameter flow cytometric measurements of cyclin B1 expression $v s$ DNA content following $8 \mathrm{~h}$ of exposure to taxol

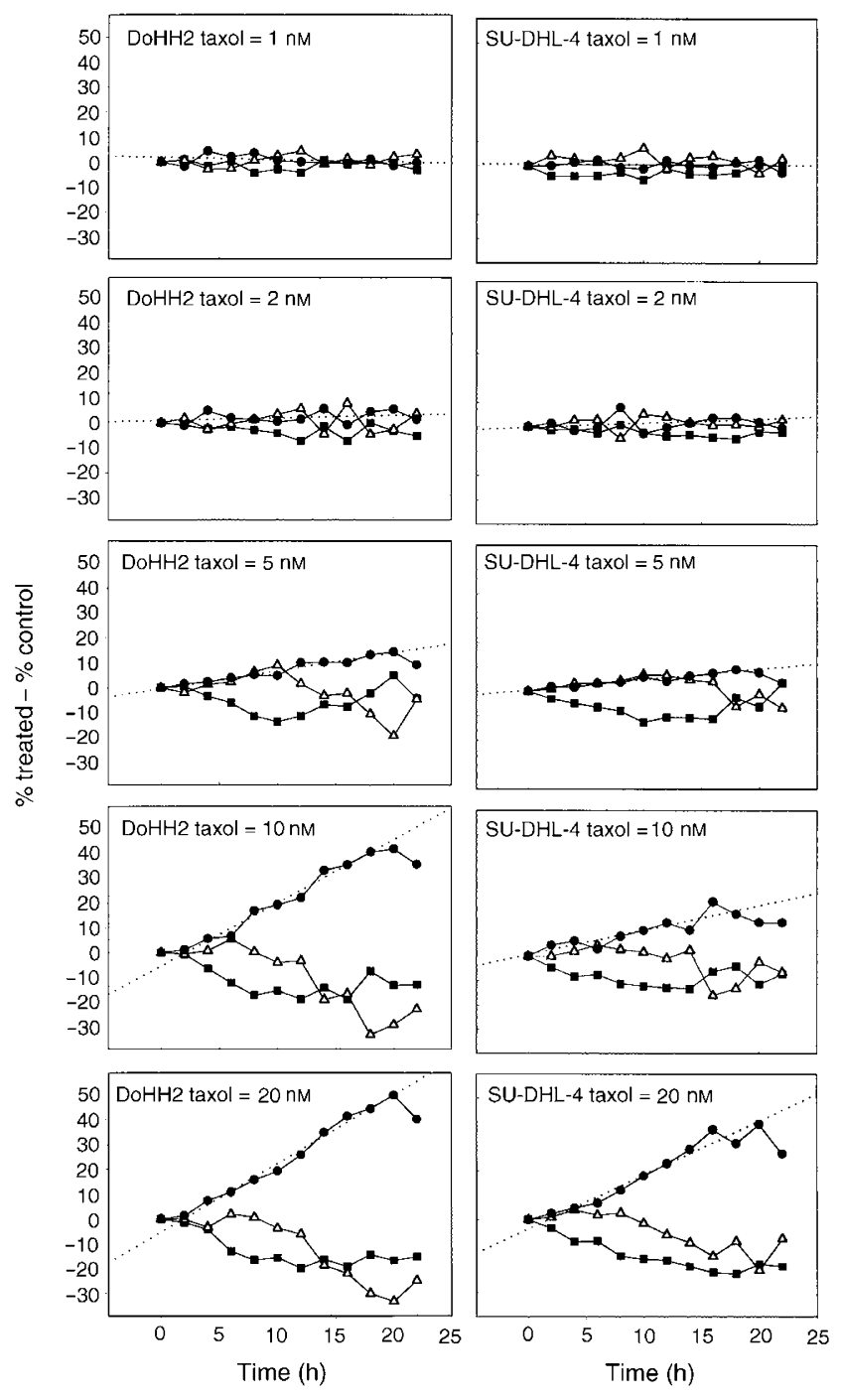

Figure 3 Dose dependency of the kinetics of cell-cycle perturbation induced in $\mathrm{DoHH} 2$ and SU-DHL-4 by continuous exposure to taxol at 2, 5 , 10 , or $20 \mathrm{~nm}$. DNA histograms were deconvoluted and the results plotted as percentage of cells in each particular cell-cycle phase, $G \mid(\boldsymbol{\square}), S(\triangle)$, $\mathrm{G} 2 / \mathrm{M}+\mathrm{G}$ I polyploid $(\mathbf{)})$, relative to those of an untreated population. The dotted line in each panel represents a linear regression analysis of the G2/M curve. The rates (\%/h) of accumulation in G2/M following exposure to $1,2,5,10$, or $20 \mathrm{nM}$ taxol are: $\mathrm{DoHH} 2=0.09,0.11,0.72,2.55,2.76$ SU-DHL-4=0.02, 0.17, 0.43, I.0I, 2.22

consistently indicated that the percentage of cells expressing cyclin B1 during G2/M was increased following exposure to all of the concentrations of taxol tested $(1,2,5,10,20 \mathrm{nM})$ (Figure 5). Following a $24 \mathrm{~h}$ exposure to taxol however, the number of SU-DHL-4 cells in G2/M expressing cyclin B1 was reduced, at all drug concentrations. In contrast, levels in the DoHH2 line remained similar to those obtained at $8 \mathrm{~h}$. This pattern of results is consistent with the view that the SU-DHL-4 cells are escaping cell-cycle arrest at the $24 \mathrm{~h}$ measurement point. However, it is also apparent that both cell lines exhibit increased cyclin B1 expression at doses of taxol that did not induce a measurable G2/M arrest on the basis of single parameter DNA measurements. Cyclin B1 is known to be associated with microtubules (Jackman et al, 1995) and our observations suggest that taxol-induced tubulin polymerisation, at concentrations insufficient to induce a cell-cycle arrest, can stabilise cyclin B1 levels. 

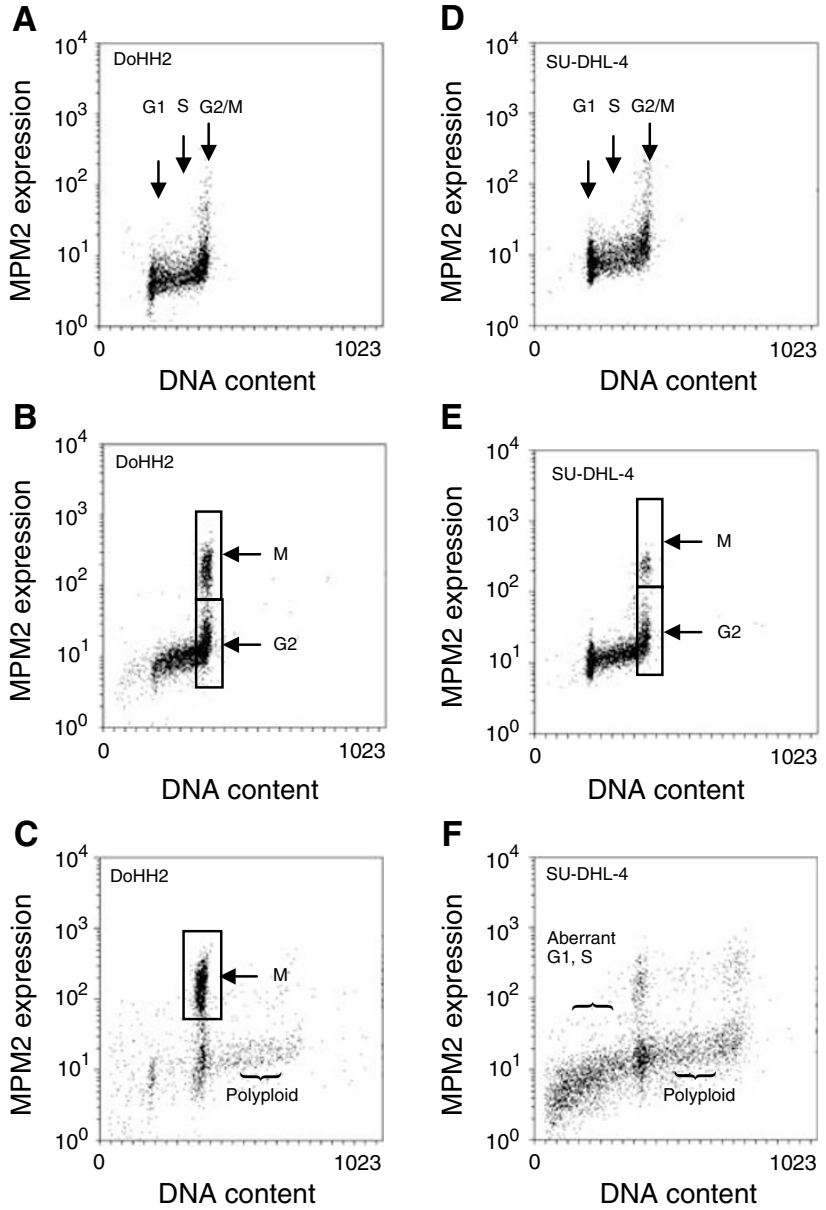

Figure 4 Dual parameter measurement of the mitotic protein MPM2 expression vs DNA content obtained during normal exponential growth (A) $\mathrm{DoHH} 2$, (D) $\mathrm{SU}-\mathrm{DHL}-4$, and following $8 \mathrm{~h}$ exposure to $10 \mathrm{nM}$ taxol (B) $\mathrm{DoHH} 2$, (E) SU-DHL-4, and following $24 \mathrm{~h}$ exposure to $10 \mathrm{~nm}$ taxol (C) $\mathrm{DoHH}$ 2, (F) SU-DHL-4. Data are representative distributions obtained from 10000 cells.

\section{Taxol induces aberrant mitoses in both DoHH2 and SU-DHL-4 cells}

Confocal laser scanning microscopy was performed in order to obtain high-resolution spatial information on tubulin structures and associated chromatin condensation. The results confirmed that taxol induced the formation of aberrant mitotic spindles with a concomitant abnormal chromosome segregation in both cell lines (Figure 6). All of the observed mitoses in DoHH2 or SU-DHL4 following exposure to taxol displayed abnormal mitotic spindles and chromatin segregation. These abnormal mitoses were all first cycle events and were similar in appearance for both the cell lines, with the formation of a tripolar mitotic spindle being the predominant aberrant feature following exposure to taxol. In order to confirm the lack of p53-dependency in these observations, we have extended our studies to include observations of isogenic thyroidderived (K1E7) cell lines, which differ only in TP53 status (Wyllie et al, 1999). Using a time-lapse microscopy approach, we have confirmed that taxol induces similar first cycle abnormal mitoses in both wild-type and mutant p53 backgrounds (data not shown).

\section{Taxol induces cell-cycle arrest in both G2 and mitosis}

Discrimination between G2 and M on the basis of dual parameter side-scatter vs DNA content (Epstein et al, 1988) allowed us to further clarify the taxol-induced accumulation of cells in G2/M.
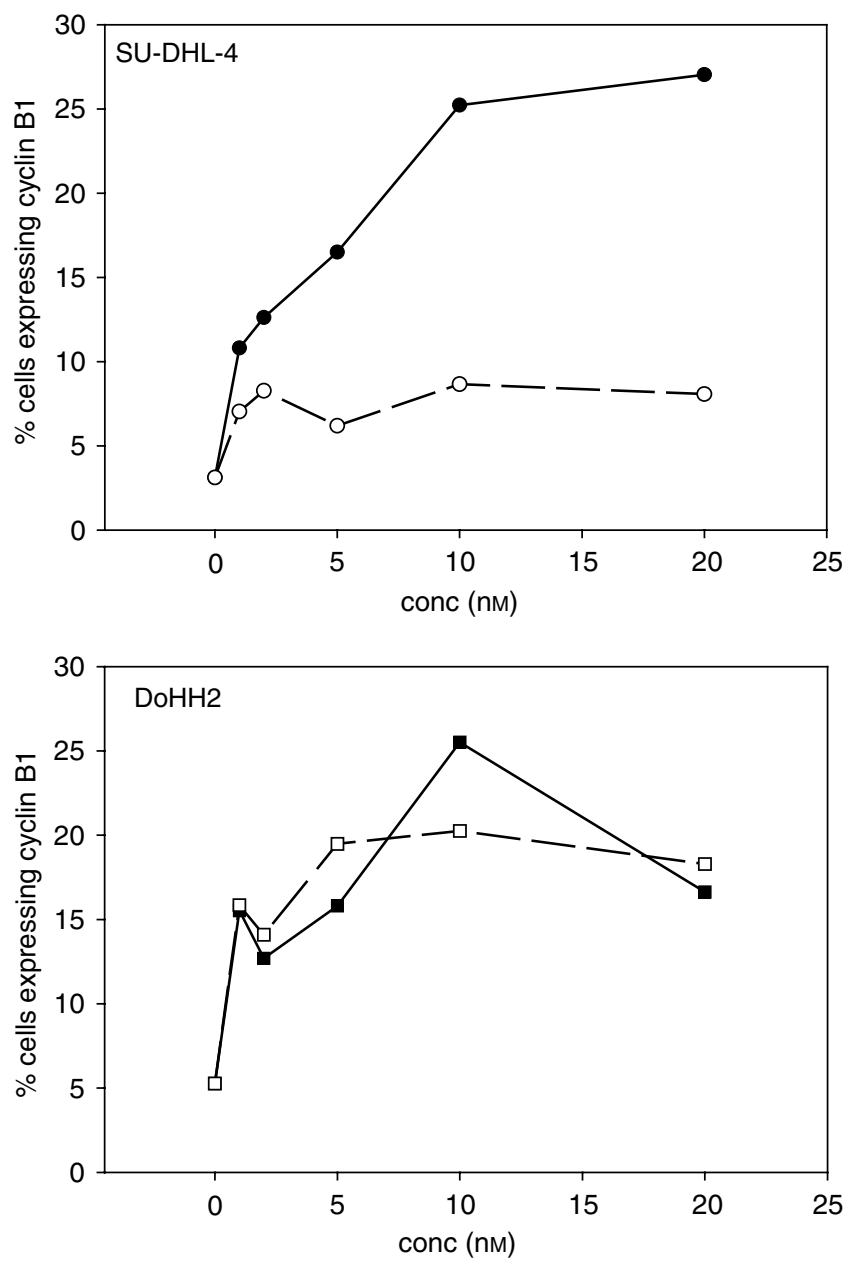

Figure 5 Changes in the percentage of cells expressing cyclin $\mathrm{BI}(\mathbf{A})$ SU-DHL-4 and (B) DoHH2 following either $8 \mathrm{~h}$ (closed symbols) or $24 \mathrm{~h}$ (open symbols) of exposure to $0,1,2,5,10,20 \mathrm{~nm}$ taxol. Cells were labelled with anticyclin BI monoclonal antibody and analysed by flow cytometry. Data shown from a representative analysis of 6000 cells.

This methodology detects a mitotic subpopulation that excludes prophase cells and is based on light scatter changes associated with nuclear chromosome condensation and the breakdown of the nuclear membrane that defines the start of prometaphase and continues through until telophase. Figure 7 illustrates the differential accumulation of cells in G2 and mitosis based on this discrimination, following exposure to taxol. It can be seen that taxol induces an accumulation of cells in both G2 and M in both the cell lines. However, in the SU-DHL-4 cell line, the number of cells arrested during mitosis is greatly reduced compared to the DoHH2 line, in agreement with the data presented in Figures 4 and 5. There is also an early and sustained increase in the number of cells with a G2 DNA content. Analysis of single parameter DNA histograms infers that SU-DHL-4 cells do not maintain a mitotic arrest, but proceed to polyploidy. We therefore suggest that the observed increase in the number of cells exhibiting a G2 DNA content is composed both of cells experiencing a G2 delay and also those cells that have undergone an abnormal mitotic exit and are G1 polyploid (with 4 N DNA content).

\section{Taxol induces apoptosis in p53 wild-type and p53 mutant} lymphoma cells

Annexin-V-FITC labelling of DoHH2 and SU-DHL-4 cells indicated that both cell lines respond to taxol in a dose-dependent 

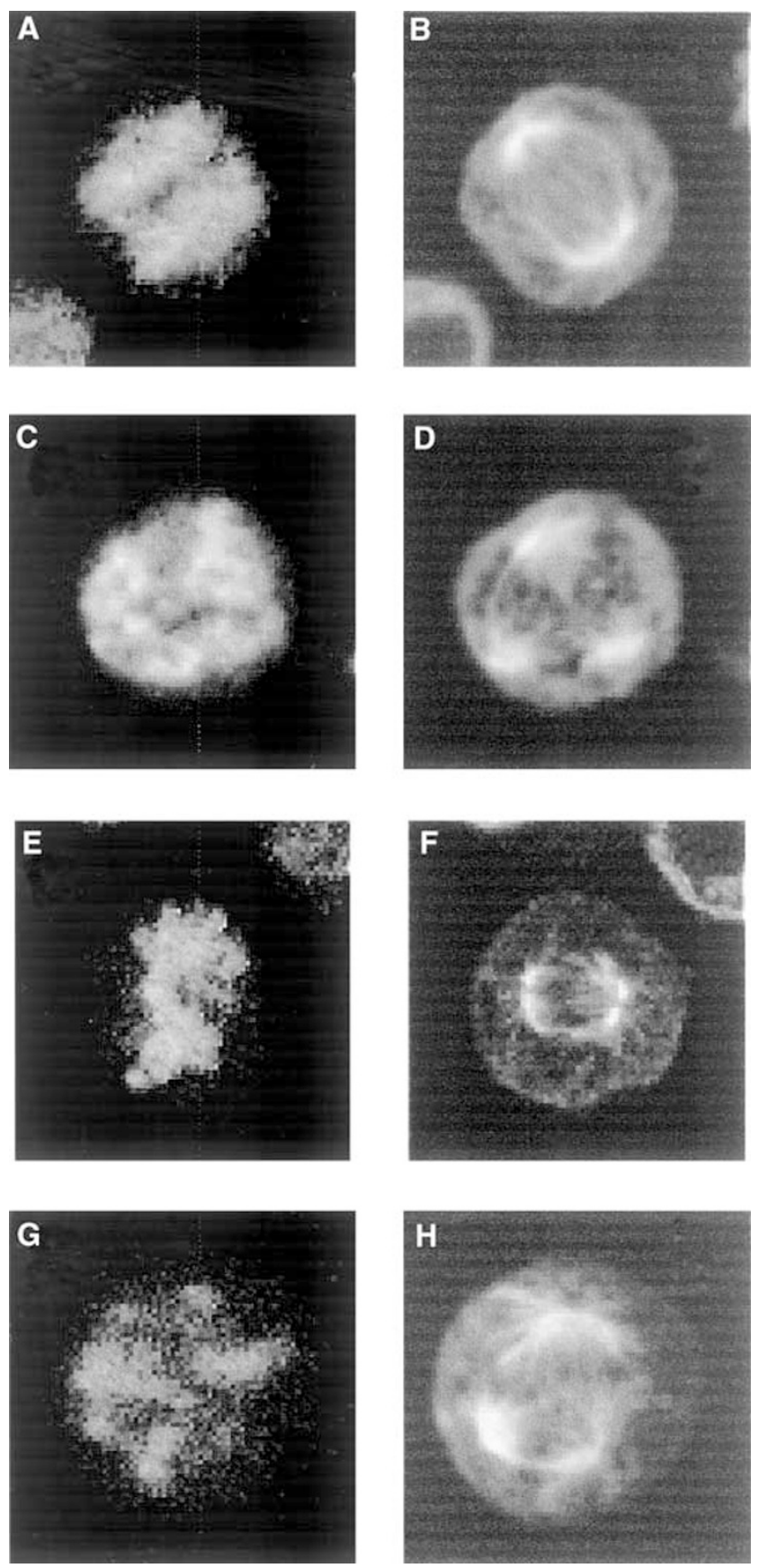

Figure 6 Laser scanning confocal fluorescence images showing normal chromatin segregation and mitotic spindle formation in $\mathrm{DoHH} 2(\mathbf{A}$ and $\mathbf{B})$ and SU-DL-4 (C and D) cells and the aberrant chromosome distribution and tripolar mitotic spindle formation induced by exposure to $20 \mathrm{nM}$ taxol in $\mathrm{DoHH} 2$ (E and $\mathbf{F})$ and SU-DHL-4 (G and $\mathbf{H})$.

manner by proceeding to apoptosis (Figure 8); however, the response differs between the two cell lines. Thus, $5 \mathrm{~nm}$ taxol elicits over a $90 \%$ induction of apoptosis in the DoHH2 cell line during the course of $72 \mathrm{~h}$ exposure, whereas only approximately $20 \%$ of the SU-DHL-4 line are induced to undergo apoptosis by $5 \mathrm{~nm}$ taxol over the same time period. Using these terms of reference, we can state that the DoHH2 cell line is more 'sensitive' to taxol than the SU-DHL-4 line.

One striking feature of the data is that it appears that the time for onset of apoptosis for a given cell line $(8 \mathrm{~h} \mathrm{DoHH} 2 ; 24 \mathrm{~h}$ SU-DHL-4) following drug exposure is remarkably constant and

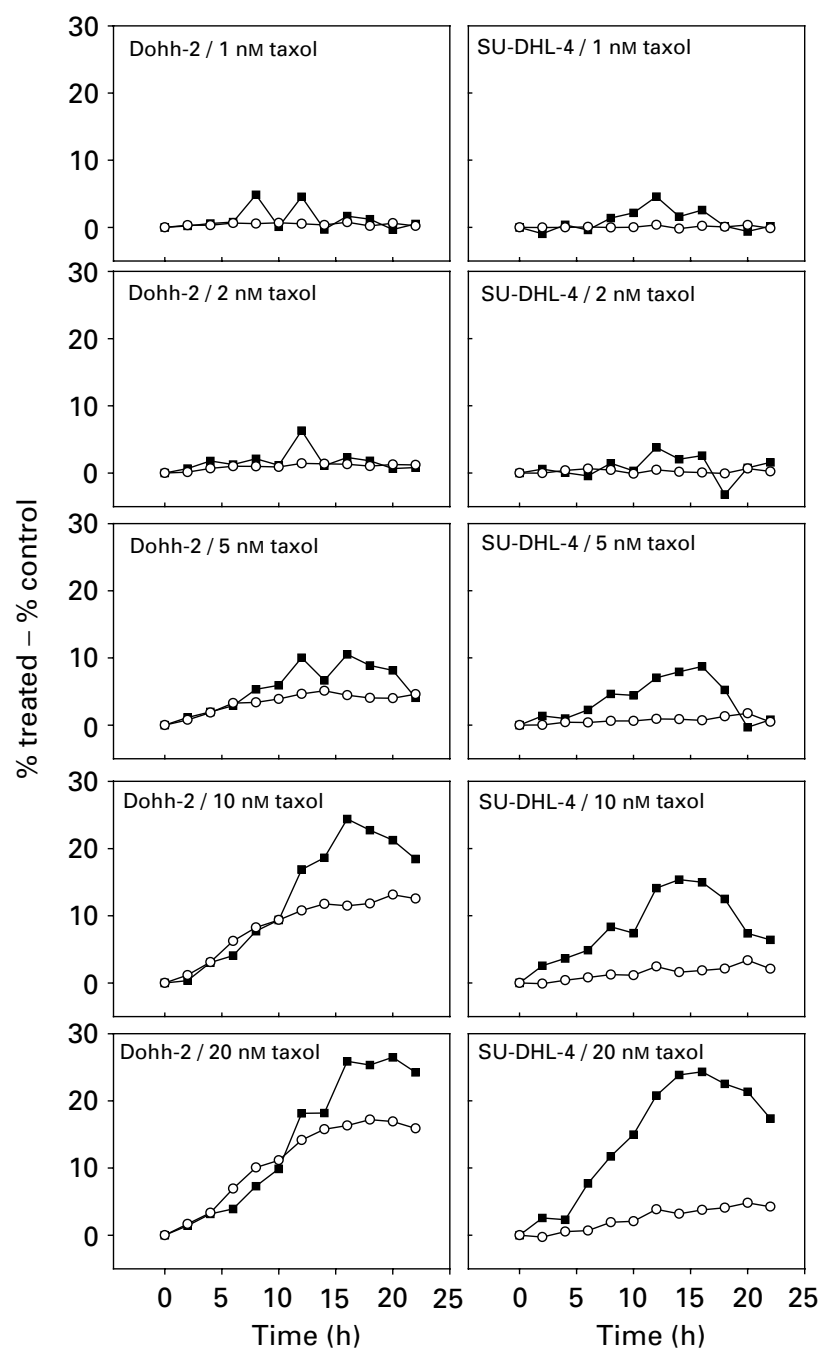

Figure 7 Differential kinetics of cell-cycle arrest in G2 (+G| polyploid) (O) and mitosis ( following exposure to taxol at 2, 5, 10, or $20 \mathrm{~nm}$. Discrimination of $\mathrm{G} 2 / \mathrm{G} / \mathrm{pol}$ and $\mathrm{M}$ was on the basis of side-scatter vs DNA content.

dose-independent, once an apoptotic threshold condition is reached. We can interpret this observation as either a threshold continuous exposure period that is required before cell death occurs, or a fixed delay period (lag) that occurs after the initial insult during which the apoptotic mechanism is engaged. It is apparent from an examination of the data obtained following exposure to $5 \mathrm{~nm}$ taxol that a prior cell-cycle arrest per se is not a prerequisite for the induction of apoptosis by this agent.

Following the initial delay period, once the apoptotic events start to appear, the rate at which the apoptotic population expands with time is remarkably similar for both cell lines and this rate appears to reach a maximum of approximately $2 \%$ per h. For a $P$-value $<0.05$, the correlation coefficients, $r$, for the rate of $G 2 / \mathrm{M}$ accumulation $v s$ the rate of appearance of apoptotic cells (annexin positive) are 0.90 for DoHH2 and 0.93 for SU-DHL-4 (Figure 9). This significant correlation suggests a causal link between the rate at which cells arrive at mitosis (that may or may not comprise a functional checkpoint) and the subsequent rate of apoptosis. Although we have fitted a straight line for both data sets (because of the number of data points), we recognise the possibility of more complex relations between $\mathrm{G} 2 / \mathrm{M}$ arrest and apoptosis. We suggest that at low doses (1-5 nM), although cells experience 'mitotic stress', it is either insufficient to induce a complete cell-cycle arrest 

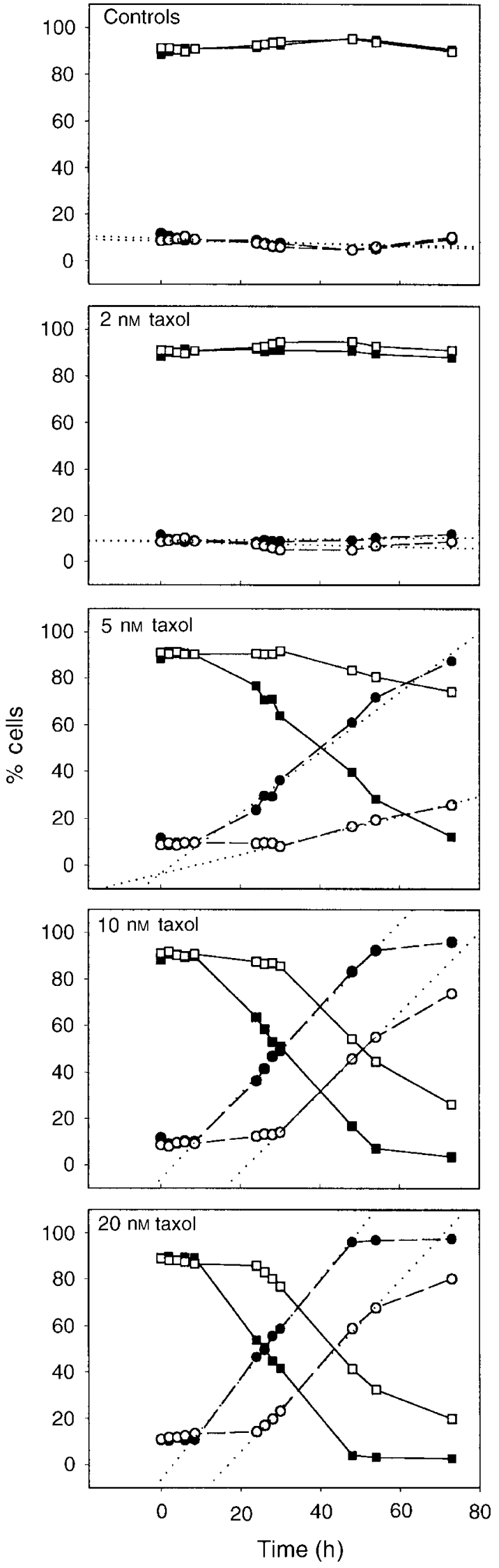

Time (h)
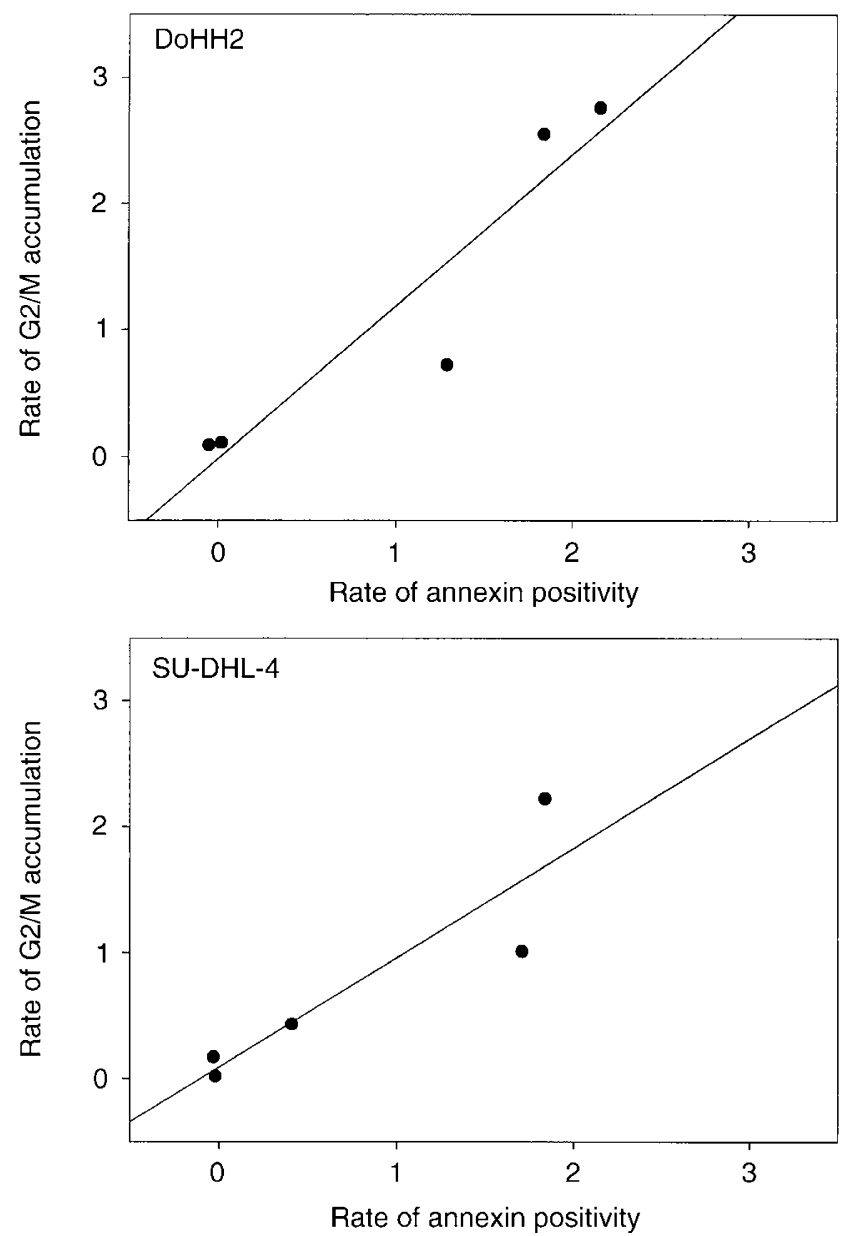

Figure 9 Correlation analysis illustrating the relation between the rate of appearance of annexin-positive cells and the rate of cell-cycle arrest in G2/ $\mathrm{M}$ for $\mathrm{DoHH} 2$ and SU-DHL-4.

or that many cells rapidly breach or exit this arrest. At higher doses $(20 \mathrm{~nm})$, both the rate of $\mathrm{G} 2 / \mathrm{M}$ accumulation and apoptosis may be reaching maximum levels. With these considerations aside, the relation between the two events still holds, that is, the prior rate of experience of a cell-cycle perturbation (experience of mitosis) is influencing the subsequent rate of cell death in both the cell types.

\section{DISCUSSION}

This study has provided a detailed time analysis of cell-cycle disruption following continuous exposure to low concentrations (1-20 nM) of taxol. Cell-cycle events have been correlated with the onset and subsequent kinetics of cell death in two lymphoma cell lines that differ in their capacity to execute rapidly apoptosis. Importantly, the concentrations of taxol used were within the clinically relevant range of achievable plasma drug concentrations (Huizing et al, 1993) and were therefore at a level that mitotic spindle-associated microtubules were preferentially targeted rather

Figure 8 Differential kinetics of the apoptotic response in DoHH2 and SU-DHL-4 following continuous exposure to $0,2,5$, I0, or $20 \mathrm{nM}$ taxol. Key: Live DoHH2 (ם), annexin-positive DoHH2 (-) live SU-DHL-4 ( $\square$ ), annexin-positive SU-DHL-4 (O). The dotted lines in each panel represent a linear regression analysis of the straight line region of the annexin-positive curves. The rates of appearance of apoptotic cells following exposure to 0 , $2,5,10$, and $20 \mathrm{nM}$ taxol are as follows: $\mathrm{DoHH} 2=-0.05,0.02,1.29,1.84$, 2.16; SU-DHL-4=-0.02, $-0.03,0.4 \mathrm{I}, \mathrm{I} .7 \mathrm{I}, \mathrm{I} .84$. 
than the overall cytoskeleton-associated microtubule system (Jordan et al, 1993). Nonlimiting doses of taxol permit cells to escape cycle arrest, arising from spindle disruption, providing an opportunity to track apoptotic engagement in potentially therapeutically important subpopulations. Our hypothesis was that although cell death may occur at different stages of progression through mitosis and subsequent cell cycles (Allman and Smith, 2002), the overall kinetics of cell death will relate to the rate of arrival at a 'critical event window' in the cell cycle. The results suggest a direct relation between the rate of delivery to a late cellcycle stage and the subsequent kinetics of cell death. The results also suggest that the net effectiveness of low doses of taxol will be driven primarily by the proliferation kinetics of a tumour cell population despite any differential capacity to rapidly engage cell death pathways as a consequence of genetic status. The findings underline the importance of tracking event resolution over a sufficiently long period to obtain an accurate determination of net effect. Furthermore, our multiparameter analyses of the kinetics of taxol responses in cells with differential capacity to rapidly engage cell death may indicate new rationales for combining taxol with other anticancer agents.

Microtubules are intrinsically dynamic polymers (Wilson and Jordan, 1995) and previous reports have suggested that treatment with high concentrations of taxol induces a cell-cycle arrest in mitosis (Schiff and Horwitz, 1980), which is associated with an increased microtubule polymer mass (Jordan et al, 1993). However, treatment of cells with low concentrations of taxol $(10 \mathrm{~nm})$ has been suggested to induce a mitotic block by suppressing microtubule dynamics rather than by altering the microtubule polymer mass or inducing bundle formation (Jordan et al, 1993). This suggests that the nature of the stress experienced during mitosis, even under conditions of minimal mitotic delay (SU-DHL-4), may be associated with a critical impact of altered microtubule dynamics during mitosis rather than spindle checkpoint activation per se.

That p53 plays an important role in the initiation and extent of arrest of cell-cycle progression following DNA damage is now well established (Kastan et al, 1991; Kuerbitz et al, 1992). The contribution of damage surveillance mechanisms, including wildtype $\mathrm{p} 53$, to cell survival following exposure to antitubulin agents is not clear (see the introductory paragraphs), although p53 protein appears to participate in the spindle checkpoint to ensure correct DNA replication before mitosis (Cross et al, 1995). p53 has been reported to be a microtubule-associated protein (Maxwell et $a l, 1991)$ and this raises the possibility that p53 is able to monitor the status of microtubules directly. Aberrant p53 function can suppress apoptosis following DNA damage resulting in a phenotype that is both radiation- and chemoresistant. In contrast, a number of reports have suggested that loss of wild-type p53 function sensitises cells to the action of taxol resulting in both increased G2/M arrest and increased apoptosis.

Formal analysis of p53 involvement in taxol responses will require the analysis of isogenic lines with differential p53 expression and these studies are in progress. Here, we have concentrated on the more specific low-dose effects in a kinetically matched system accessible to high-resolution analysis. Importantly, overall apoptotic kinetics have been appreciated by extended tracking of treated cultures.

These results are in agreement with previous reports that continued DNA replication, in permissive cells, in the presence of mitotic spindle inhibitors results in a drive to polyploidy and abnormal mitotic exit (Jordan et al, 1996; Di Leonardo et al, 1997). The G1/S competence of DoHH2 may contribute to a postmitotic G1 arrest in agreement with previous studies (Khan and Wahl, 1998; Notterman et al, 1998). The development of polyploidy has also been associated with increasing taxol resistance in leukaemia cell lines (Roberts et al, 1990). Abnormal mitotic spindle formation prior to the development of polyploidy was confirmed in the present study by confocal microscopy. In both cell lines a similar range of aberrations were observed, with the presence of tripolar spindles being a predominant feature. Confirming studies (data not shown) using a different cell type (Wyllie et al, 1999) also revealed a p53-independence of the formation of such aberrant spindles and mitoses for isogenic thyroid-derived K1E7 cells.

The cell lines have similar cell-cycle kinetics, but differential apoptotic responses (Smith et al, 1994, 2002). However, a striking feature apparent in the current data is that there is a fixed delay period prior to the onset of apoptosis, which is constant within a given cell line irrespective of taxol dose. Our imaging studies indicate that it is unlikely that the differences in this delay period for the two cell lines relate to differences in the ability of taxol to effect microtubule disruption per se. Total exposure time to taxol appears to be less important than whether cells deliver to a critical cell-cycle event during exposure. After this critical event, apoptotic response rate is clearly dose-dependent. It is reasonable to suggest that overt expression of apoptosis merely takes longer in SU-DHL4 cells. There is a significant correlation $(P<0.05)$ between the rate of accumulation of cells in G2/M and the rate of increase of the number of apoptotic cells within the population and this observation is consistent with the hypothesis that the rate at which cells experience mitotic stress determines the subsequent rate of cell death.

We propose a hierarchy of events in the cellular response to taxol (Figure 10). Cells exposed to low concentrations of taxol may undergo a mitotic arrest either by checkpoint activation or by mechanical disruption of microtubules. We also incorporate the possibility that stress-activated protein kinase activity can signal mitotic arrest directly (Wang et al, 2000). Cells may subsequently proceed to apoptosis directly (which is rapid) or, in cells that are not subject to a cell-cycle arrest in mitosis, may proceed to undergo a delayed induction of apoptosis that follows aberrant mitotic exit and the formation of polyploid cells.

The mitotic spindle assembly checkpoint has been proposed to regulate taxol-induced apoptosis, with the checkpoint component

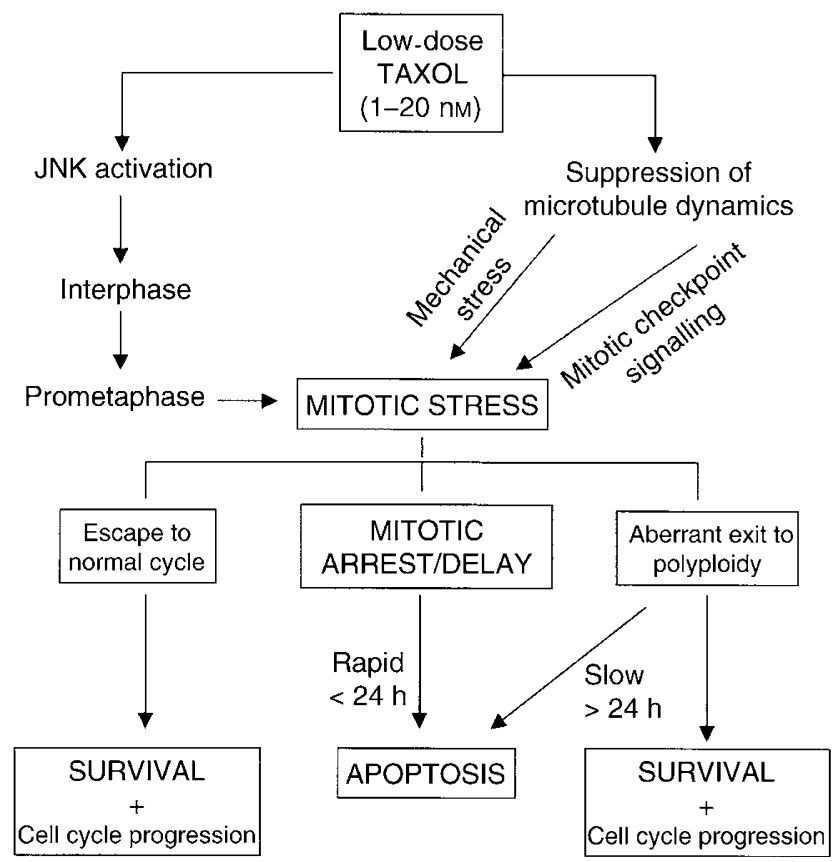

Figure 10 Proposed model of taxol-induced cell death (incorporating concepts from Wang et al, 2000) in which cells may either undergo a rapid engagement of apoptosis during mitotic arrest or a delayed engagement of apoptosis following aberrant mitotic exit. 
Bub1 being rapidly phosphorylated following taxol treatment (Taylor et al, 2001). Importantly, the taxol concentration used was 1000 -fold higher than those used in the present report. Here, we have demonstrated that a prior cell-cycle arrest in mitosis is not required for subsequent progression to apoptosis, that is, cell death can be induced at lower concentrations than those required for cell-cycle arrest. This suggests that taxol can trigger apoptosis without the intervention of spindle checkpoint activation, but still requires cells to experience traverse of the corresponding cell-cycle stage under altered microtubule dynamics.

The potentially wide time course over which apoptotic events may be triggered (upto $48 \mathrm{~h}$ ) provides few opportunities to correlate biochemical assays with cellular events in heterogenously responding populations monitored here. The antiapoptotic

\section{REFERENCES}

Allman R, Smith PJ (2002) Mitotic Arrest is not Required for Taxol Induced Cell Death. Proceedings of the XXI Congress of the International Society for Analytical Cytology 2002, San Diego, USA

Callahan R (1992) P53 mutations, another breast cancer prognostic factor. $J$ Natl Cancer Inst 84: 826-827

Cheng L, Zheng S, Raghunathan K, Priest DG, Willingham MC, Norris JS, Fan W (1995) Characterisation of Taxol-induced apoptosis and altered gene expression in human breast cancer cells. Cell Pharmacol 2: 249-257

Cross SM, Sanchez CA, Morgan CA, Schimke MK, Ramel S, Idzerda RL, Raskind WH, Reid BJ (1995) A p53-dependent mouse spindle checkpoint. Science 267: 1353-1356

De Brabender M, Geuens G, Nuydens R, Willebrords R, Aerts F, De Mey J (1996) Microtubule dynamics during the cell cycle: the effects of Taxol and nocodozole on the microtubule system of pt K2 cells at different stages of the mitotic cycle. In International Review of Cytology, Bourne GH, Danielli JF, Jeon KW (eds) pp 215-274. Orlando: Academic Press

Di Leonardo A, Khan SH, Linke SP, Greco V, Seidita G, Wahl GM (1997) DNA rereplication in the presence of mitotic spindle inhibitors in human and mouse fibroblasts lacking either p53 or pRb function. Cancer Res 57: $1013-1019$

Edelman MJ, Gandara DR (1996) Promising new agents in the treatment of non-small cell lung cancer. Cancer Chemother Pharmacol 37: 385-393

Einzig AI, Wiernik PH (1995) Melanoma. In Paclitaxel in Cancer Treatment, McGuire WP, Rowinsky EK (eds) pp 321-327. New York: Marcel Dekker Inc

Epstein AL, Levy R, Kim H, Henle W, Henle G, Kaplan HS (1978) Biology of the human malignant lymphomas IV. Functional characterization of ten diffuse histiocytic lymphoma cell lines. Cancer 42: 2379-2391

Epstein RJ, Watson JV, Smith PJ (1988) Subpopulation induced cellcycle delay in human tumour cells using $90^{\circ}$ light scatter. Cytometry 9: $349-358$

Etlinger DS (1993) Overview of paclitaxel (Taxol) in advanced lung cancer. Semin Oncol 20: 46-49

Forastiere AA (1993) Use of paclitaxel (Taxol) in squamous cell carcinoma of the head and neck. Semin Oncol 20: 56-60

Giodini A, Kallio MJ, Wall NR, Gorbsky GJ, Tognin S, Marchisio PC, Symons M, Altieri DC (2002) Regulation of microtubule stability and mitotic progression by survivin. Cancer Res 62: $2462-2467$

Gong J, Traganos F, Darzynkiewicz Z (1995) Discrimination of G2 and mitotic cells by flow cytometry based on different expression of cyclins A and B1. Exp Cell Res 220: 226-231

Graniela Sire EA, Vikhanskaya F, Broggin M (1995) Sensitivity and cellular response to different anticancer agents of a human ovarian cancer cell line expressing wild-type, mutated, or no p53. Ann Oncol 6: 589-593

Holmes FA, Walters RS, Theriault AT, Forman AD, Newton LK, Raber MN, Buzdar AC, Fry DK, Hortobagyi GN (1991) Phase II trial of Taxol, an active drug in the treatment of metastatic breast cancer. J Natl Cancer Inst 83: 1797 - 1805

Hortobagyi GN, Holmes (1996) Single-agent paclitaxel for the treatment of breast cancer: an overview. Semin Oncol 23 (1 Suppl 1): 4-9

Horwitz SB, Lothstein L, Manfredi JJ, Mellado W, Parness J, Roy SN, schiff PB, Sorbana L, Zeheb R (1986) Taxol: mechanism of action and resistance. Ann NY Acad Sci 466: $733-744$

Huizing MT, Keung ACF, Rosing H, van der Kuij V, Bokkel Huinink WW, Mandjes IN, Dubbelman AC, Pinedo HM, Beijnen JH (1993) Pharmacokinetics of paclitaxel and metabolites in a randomised comparative protein survivin has been demonstrated to control microtubule stability and assembly of mitotic spindles and can act to override apoptosis induced by taxol (Li et al, 1998; Giodini et al, 2002). The relative expression of survivin in different cell systems may therefore also contribute to observed differences in the kinetics of response to taxol. Defining the kinetics of cellular responses to taxol-induced stress in terms of checkpoint activation, cell-cycle arrest, and apoptosis will contribute to a coherent view as to how different agents with different cellular targets may be combined with taxol to enhance therapeutic effectiveness. This is of particular importance where combinations of agents may abrogate taxol activity. We are currently investigating this approach using combinations of ionising radiation and taxol. study in platinum-pretreated ovarian cancer patients. J Clin Oncol 11: $2127-2135$

Jackman M, Firth M, Pines J (1995) Human cyclins B1 and B2 are localised to strikingly different structures: $\mathrm{B} 1$ to microtubules, $\mathrm{B} 2$ primarily to the Golgi apparatus. EMBO J 14: 1646-1654

Jordan MA, Toso RJ, Thrower D, Wilson L (1993) Mechanism of mitotic block and inhibition of cell proliferation by Taxol at low concentrations. Proc Natl Acad Sci USA 90: 9552-9556

Jordan MA, Wendell K, Gardiner S, Derry BW, Copp H, Wilson L (1996) Mitotic block induced in HeLa cells by low concentrations of paclitaxel (Taxol) results in abnormal mitotic exit and apoptotic cell death. Cancer Res 56: $816-825$

Juan G, Traganos F, Darzynkiewicz Z (2001) Methods to identify mitotic cells by flow cytometry. Methods Cell Biol 63: 343-354

Kastan MB, Onyekwere O, Sidransky D, Vogelstein B, Craig RW (1991) Participation of $\mathrm{p} 53$ protein in the cellular response to DNA damage. Cancer Res 51: 6304-6311

Khan SH, Wahl GM (1998) P53 and pRb prevent rereplication in response to microtubule inhibitors by mediating a reversible G1 arrest. Cancer Res 58: $396-401$

Kluin-Nelemans HC, Limpens J, Meerabux J, Beverstock GC, Jansen JH, de Jong D, Kluin PM (1991) A new non-Hodgkin's B-cell line (DoHH2) with a chromosomal translocation $\mathrm{t}(14,18)(\mathrm{q} 32$, q21). Leukemia 5: $221-224$

Kuerbitz SJ, Plunkett BS, Walsh WV, Kastan MB (1992) Wild-type p53 is a cell cycle checkpoint determinant following irradiation. Proc Natl Acad Sci USA 89: $7491-7495$

Li F, Ambrosini G, Chu EY, Plescia J, Tognin S, Marchisio PC, Altieri DC (1998) Control of apoptosis and mitotic spindle checkpoint by survivin. Nature 396: $580-584$

Lowe SW, Ruley HE, Jacks T, Housman DE (1993a) p53-dependent apoptosis modulates the cytotoxicity of anticancer agents. Cell 74: 957-967

Lowe SW, Schmitt EM, Smith SW, Osborne BA, Jacks T (1993b) p53 is required for radiation induced apoptosis in mouse thymocytes. Nature 362: $847-849$

Manfredi JJ, Horwitz SB (1984) Taxol: an antimitotic agent with a new mechanism of action. Pharmacol Ther 25: 83-125

Manfredi JJ, Parness J, Horwitz SB (1982) Taxol binds to cellular microtubules. J Cell Biol 94: 688-696

Martinez-Exposito MJ, Kaplan KB, Copeland J, Sorger PK (1999) Retention of the Bub3 checkpoint protein on lagging chromosomes. Proc Natl Acad Sci USA 96: 8493-8498

Maxwell SA, Ames SK, Sawai ET, Decker GL, Cook RG, Butel JS (1991) Simian virus 40 large $\mathrm{T}$ antigen and p53 are microtubule associated proteins. Cell Growth Differ 2: 115-127

McGuire WP, Rowinsky EK, Rosenshine NB, Grumbine FC, Ettinger DS, Armstrong DK, Donehower RC (1989) A unique antineoplastic agent with significant activity in advanced ovarian epithelial neoplasms. Ann Intern Med 111: 273-279

Milross CG, Mason KA, Hunter NR, Chung WK, Peters LJ, Milas L (1996) Relationship of mitotic arrest and apoptosis to antitumour effect of paclitaxel. J Natl Cancer Inst 88: 1308-1314

Notterman D, Young S, Wainger B, Levine AJ (1998) Prevention of mammalian DNA reduplication following the release from mitotic spindle checkpoint requires p53 protein but not p53 mediated transcriptional activity. Oncogene 17: 2743-2751 
Ormerod MG, Payne AWR, Watson JV (1987) Improved program for the analysis of DNA histograms. Cytometry 8: 637-641

Pines J, Hunter T (1989) Isolation of human cyclin cDNA: evidence for cyclin mRNA and protein regulation in the cell cycle and for interaction with p34 ${ }^{\text {cdc2 }}$. Cell 58: $833-846$

Rao S, Horwitz SB, Ringel I (1992) Direct photoaffinity labelling of tubulin with Taxol. J Natl Cancer Inst 84: 785-788

Rao S, Krauss NE, Heerding JM, Swindell CS, Ringel I, Orr GA, Horwitz SB (1994) 3'-(p-azidobezamido)Taxol photolabels the N-terminal 31 amino acids of $\beta$-tubulin. J Biol Chem 269: $3132-3134$

Roberts JR, Allison DC, Donehower RC, Rowinsky EK (1990) Development of polyploidization in taxol-resistant human leukaemia cells in vitro. Cancer Res 50: 710-716

Rowinsky EK, Cazenave LA, Donehower RC (1990) Taxol: a novel investigational antimicrotubule agent. J Natl Cancer Inst 82: 1247-1259

Rowinsky EK, Onnetto N, Cannetta RM, Arbuck SG (1992) Taxol: the first of the taxanes, an important new class of antitumour agents. Semin Oncol 19: $646-662$

Rowinsky EK, Tucker RW, Burke PJ, Ettinger D, Donehower RC (1989) Phase I and pharmacodynamic study of Taxol in refractory acute leukemias. Cancer Res 49: $4640-4647$

Runowicz CD, Fields AL, Goldberg GL (1995) Promising new therapies in the treatment of advanced ovarian cancer. Cancer 76 (Suppl 10): $2028-2033$

Schiff PB, Fant J, Horwitz SB (1979) Promotion of microtubule assembly in vitro by Taxol. Nature (London) 277: 665-667

Schiff PB, Horwitz SB (1980) Taxol stabilizes microtubules in mouse fibroblast cells. Proc Natl Acad Sci USA 77: 1561-1565

Schiff PB, Horwitz SB (1981) Taxol assembles tubulin in the absence of exogenous guanosine 5-triphosphate or microtubule-associated proteins. Biochemistry 20: $3247-3252$

Slichenmyer WJ, von Hoff DD (1991) Taxol: a new and effective anti-cancer drug. Anti-Cancer Drugs 2: 519-530

Smith PJ, Blunt N, Wiltshire M, Hoy T, Teesdale-Spittle P, Craven MR, Watson JV, Amos WB, Errington RJ, Patterson LH (2000a) Characteristics of a novel deep red/infrared fluorescent cell-permeant DNA probe DRAQ5, in intact human cells analysed by flow cytometry, confocal and multiphoton microscopy. Cytometry 40: 280-291

Smith PJ, Rackstraw C, Cotter F (1994) DNA fragmentation as a consequence of cell cycle traverse in doxorubicin and idarubicin treated human lymphoma cells. Ann Haematol 69: 7-11
Smith PJ, Wiltshire M, Chin SF, Rabbits P, Soues S (2000b) Cell cycle checkpoint evasion and protracted cell cycle arrest in X-irradiated smallcell lung carcinoma cells. Int J Radiat Biol 9: 1137-1147

Smith PJ, Wiltshire M, Davies S, Suet-Feung Chin, Cambell AK, Errington RJ (2002) DNA damage-induced $\left[\mathrm{Zn}^{2+}\right]$ transients correlation with cell cycle arrest and apoptosis in lymphoma cells. Am J Physiol-Cell Physiol 283: $c 609-c 622$

Sorger PK, Dobles M, Tournebize R, Hyman AA (1997) Coupling cell division and cell death to microtubule dynamics. Curr Opin Cell Biol 9: 807-814

Taylor SS, Hussein D, Wang Y, Elderkin S, Morrow CJ (2001) Kinetochore localization and phosphorylation of the mitotic checkpoint components Bub1 and BubR1 are differentially regulated by spindle events in human cells. J Cell Sci 114: 4385 - 4395

Taylor SS, McKeon F (1997) Kinetochore localization of murine Bub1 is required for normal mitotic timing and checkpoint response to spindle damage. Cell 89: $727-735$

Tishler RB, Lamppu DM, Park S, Price BD (1995) Microtubule-active drugs Taxol, vinblastine, and nocodozole increase the levels of transcriptionally active p53. Cancer Res 55: 6021-6025

Wahl AF, Donaldson KL, Fairchild C, Lee FY, Foster SA, Demers GW, Galloway DA (1996) Loss of normal p53 function confers sensitisation to Taxol by increasing G2/M arrest and apoptosis. Nat Med 2: $72-79$

Wang TH, Wang HS, Soong YK (2000) Paclitaxel-induced cell death: where the cell cycle and apoptosis come together. Cancer 88: 2619-2628

Wani MC, Taylor HL, Wall ME, Coggon P, McPhail AT (1971) Plant antitumour agents VI. The isolation and structure of Taxol, a novel antileukemic and antitumour agent from Taxus brevifolia. J Am Chem Soc 93: 2325 - 2327

Watson JV, Chambers SH, Smith PJ (1987) A pragmatic approach to the analysis of DNA histograms with a definable G1 peak. Cytometry 8: $1-8$

Widrow RJ, Rabinovitch PS, Cho K, Laird CD (1997) Separation of cells at different times within G2 and mitosis by cyclin B1 flow cytometry. Cytometry 27: 250-254

Wilson L, Bamburg JR, Mizel SB, Grisham LM, Cresswell KM (1974) Interaction of drugs with microtubule proteins. Fed Proc 33: 158-166

Wilson L, Jordan MA (1995) Microtubule dynamics: taking aim at moving target. Chem Biol 2: 569-573

Wu GS, El-Deiry WS (1996) P53 and chemosensitivity. Nat Med 2: 225-226

Wyllie FS, Haughton MF, owson JM, Wynford-Thomas D (1999) Human thyroid cancer cells as a source of iso-genic, iso-phenotypic cell lines with or without functional p53. Br J Cancer 79: 1111-1120 